\title{
Season-Induced Variation in Water Table Depth and Selected Chemical Parameters of Groundwater in Lagos Coastal Plain Sand Aquifer, Nigeria
}

\author{
${ }^{1 * B A L O G U N, ~ I I ; ~}{ }^{2}$ AKOTEYON, I.S; 1 SONEYE, ASO \\ ${ }^{*}$ Department of Geography, University of Lagos, Nigeria \\ ${ }^{2}$ Department of Geography and Planning, Lagos State University, Ojo, Lagos, Nigeria \\ *Corresponding Author Email: idowubalogun@yahoo.com
}

\begin{abstract}
In-situ measurement of depth to aquifer and water table was undertaken in 45 protected dug wells over two seasons. Samples were also analyzed for $\mathrm{pH}, \mathrm{EC}$, TDS, $\mathrm{Ca}, \mathrm{Cl}, \mathrm{K}, \mathrm{HCO}_{3}, \mathrm{CO}_{3}, \mathrm{SO}_{4}, \mathrm{Mg}, \mathrm{K}$, and $\mathrm{Na}$ using universally accepted laboratory techniques. The study was aimed at examining seasonal variations in the chemistry of groundwater in the Lagos Coastal Plain Sand aquifer and its potability using the WHO standards. The study area covered parts of the Lagos Metropolis and the entire settlements of Ikorodu, Epe, and Badagry. The sample locations were mapped with ArcMap 9.3 software while the data were analyzed using descriptive statistics, paired sample T-test, correlation and multivariate statistical techniques using SPSS software 17.0 version. The result shows that about $60 \%$ of the samples had pH below the WHO minimum standard of 6.5 in both the dry and wet seasons. Mean EC and TDS levels were excessively high at Igando in both seasons. Some major ions, calcium, magnesium, potassium and sodium, and chloride exceeded the WHO limit at Oko-Oba, Ilogbo, Shomolu and Shogunle in the dry season. They were also excessively high in the wet season at Igando, Oko-Oba, Odo-Onosa, Ilogbo, Shomolu, and Shogunle. Correlation analysis shows that a significant relationship exists between the parameters at $\mathrm{p}<0.05$ with the exception of $\mathrm{Mg}^{2+}$ and $\mathrm{K}^{+}$in both seasons. The result of the paired sample T-test also shows significant variations among $\mathrm{pH}, \mathrm{Ca}^{2+}, \mathrm{HCO}_{3}{ }^{-}$and $\mathrm{Mg}^{2+}$ with higher mean values in the dry than the wet season except for $\mathrm{pH}$. Factor analysis identified salinity and anthropogenic activities as the two major sources of pollution. These account for about $74.48 \%$ and $84.21 \%$ of the total variances in dry and wet seasons, respectively. Consequently, protection of the recharge areas of the aquifer from environmental pollution and formulation and enforcement of appropriate policies that will stem the rate of indiscriminate groundwater exploitation and prevention of saline water intrusion in the coastal settlements are recommended.
\end{abstract}

\section{DOI: $\underline{\text { https://dx.doi.org/10.4314/jasem.v23i8.9 }}$}

Copyright: Copyright $\left({ }^{C} 2019\right.$ Balogun et al. This is an open access article distributed under the Creative Commons Attribution License (CCL), which permits unrestricted use, distribution, and reproduction in any medium, provided the original work is properly cited.

Dates: Received: 30 March 2019; Revised: 21 July 2019; Accepted 09 August 2019

Keywords: Aquifer; Coastal Plain Sand; Groundwater; Lagos; Seasonal variations, Water quality parameters

Groundwater is a major source of water for human consumption worldwide (World Water Assessment Programme (WWAP, 2009). It is crucial for the livelihoods and food security of about 1.2 to 1.5 billion rural households in Africa and Asia (Comprehensive Assessment of Water Management in Agriculture, 2007). Groundwater also plays a vital role in the hydrological cycle by sustaining a wide range of terrestrial, aquatic and marine ecosystems (Morris et al., 2003). According to AQUASTAT (2011), the rate of groundwater abstraction is estimated at about 1,000 $\mathrm{km}^{3}$ per year comprising about $67 \%$ abstracted for irrigation, $22 \%$ for domestic, and $11 \%$ for industrial uses. In Nigeria, potential groundwater resource is estimated at about 51.9 billion $\mathrm{m}^{3}$ per annum (Federal Ministry of Water Resources (MWR, 2007). However, its availability varies with rainfall, location, and geological formations. The nation's geology is dominated by the Basement Complex Rocks (BCR) covering the greater parts of the north while the
Sedimentary rocks span the Lagos-Osse and the NigerDelta Basins. Along the coastal zone of the south west, the geology is characterized by recent littoral sandy alluvium and coastal plain sands. The major aquifer in this basin occurs in sands and overburden with shales and clays forming impermeable horizons (Longe et al., 1987). Though groundwater is reliable in terms of its quality, the increasing risks of anthropogenic activities have resulted into quality degradation which translates directly into socio-economic impacts that constitute a major global concern (United Nation Education Programmee, 2010). For instance, over-abstraction of groundwater has been implicated in the deterioration of water quality through increased concentrations of naturally occurring compounds as reported in India where fluorosis threatens millions of people (Esteller et al., 2012; UNESCO, 2012). Increased saltwater intrusion into coastal aquifers was also reported in Cyprus and the Gaza strip (Stellar, 2010). Indiscriminate disposal of liquid and solid waste, 
inorganic and organic chemicals, manure from livestock, irrigation return flows, and mining residues have also been reported as potential sources of groundwater quality deterioration (UNESCO, 2012). The introduction of chemical pollutants such as heavy metals, toxic substances, and persistent organic products (POPs) has also been found to be responsible for groundwater quality degradation. Indeed, degraded water quality is responsible for the death of about 3.5 million people annually in developing countries (WHO, 2008). These arise from water-related diseases such as diarrhea, intestinal nematode infections, trachoma, schistosomiasis, malaria, onchocerciasis, dracunculiasis, lymphatic filariasis and dengue (UNESCO, 2012). Similarly, high levels of arsenic were also detected in a pond used for water supply in Bukuru, and high fluoride in parts of Kaltungo, Billiri, Gombe, Pindiga, Dass and Langtang, as well as in some boreholes in Abia, State, Nigeria (Ince et al., 2010). The problem of saltwater intrusion was also reported to have threatened water supplies in coastal settlements around Uju, Guma and Songo areas of Benue state (Ince et al., 2010).

Methods used for water quality assessment include multivariate statistical techniques such as factor analyses, principal component analysis, cluster analysis, etc. Their uses have assisted in providing a solution to various environmental problems and a better understanding of the groundwater flow regime (Meng and Maynard, 2001; G“uler et al., 2004 and Thyne et al., 2004).

The knowledge and understanding of chemical elements in groundwater and their health implications in humans, therefore, is very important for policy formulation and wellbeing of the populace tapping from the coastal plain sand aquifer. Therefore, this study seeks to contribute and fill this gap in knowledge with the aim of examining the seasonal variations in water table depth of major ions in groundwater from the Lagos coastal plain sand aquifer.

\section{MATERIALS AND METHODS}

Description of the study area: The study area covers the Coastal Plain Sands (CPS) Aquifers of Lagos, Nigeria. It lies approximately between Latitudes $6^{0} 30$ $\mathrm{N}$ and $6^{0} 40^{\mathrm{N}} \mathrm{N}$ and Longitudes $3^{\circ} 00^{\mathrm{l}} \mathrm{E}$ and $4^{0} 00^{\mid} \mathrm{E}$ (Fig. 1). It covers parts of the Lagos Metropolis and the entire settlements of Ikorodu, Epe, and Badagry. Its area coverage is about $73.63 \mathrm{~km}^{2}$.

The climate is tropical with an average temperature of about $30^{\circ} \mathrm{C}$. Mean annual rainfall is about $1,532 \mathrm{~mm}$ (Odumosu et al., 1999). The vegetation is predominantly tropical type. The area is drained by
Rivers Abesan, Berre, Ibu, Ore and Owo. Groundwater flows generally north to south with two small cones of depression in Apapa and Ikeja due to intense groundwater abstraction.

The geology is underlain by Benin Formation and is made up of unconsolidated sands and gravels (Adelana et al., 2008). The hydrogeology is characterized by sand and clay from the underlying aquifer formation (Longe, 2011). The major aquifer formations in the area are the CPS categorized into four types namely the recent sediments/alluvium, the upper and lower CPS and the Abeokuta formation (Longe, 2011). Groundwater is found in semi-confined to unconfined aquifers consisting of sand and clay (Adelana et al., 2008). Variation in the thickness between the first and third CPS aquifers ranges between $200 \mathrm{~m}$ and $250 \mathrm{~m}$, respectively (Adelana et al., 2008) while the mean groundwater storage of the first aquifer is estimated at about $2.87 \times 10^{3} \mathrm{~m}^{3}$.

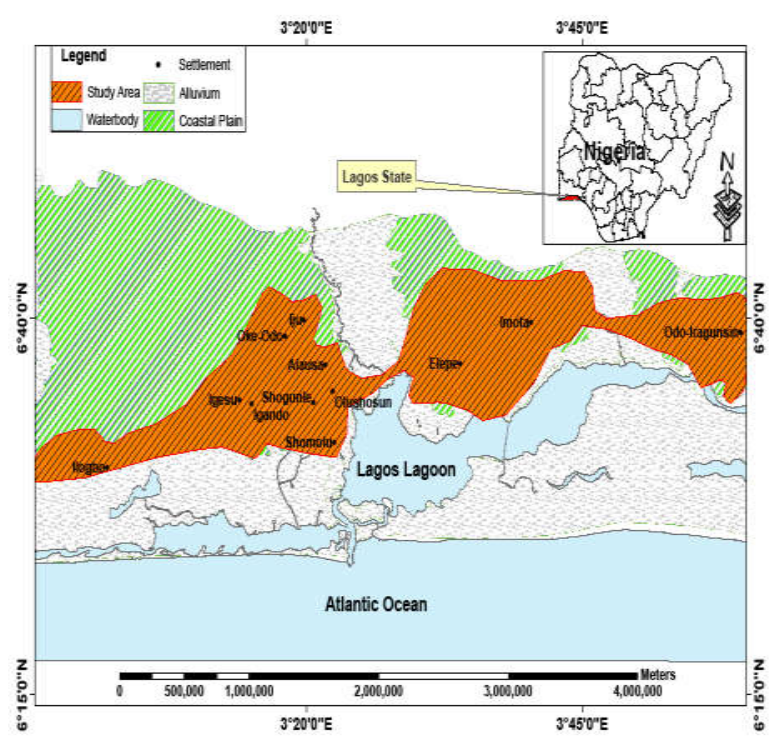

Fig. 1. The Study Area

Water table depth ranges between 0.4 and $21 \mathrm{~m}$ with an annual fluctuation of less than $5 \mathrm{~m}$ (Asiwaju-Bello and Oladeji, 2001). The water table of the upper coastal plain sand aquifer (UCPS) has an annual fluctuation that is less than $5 \mathrm{~m}$ (Asiwaju-Bello and Oladeji, 2001). It is tapped by hand-dug wells and is usually prone to pollution because it is near the ground surface. In contrast, the lower coastal plain sand (LCPS) aquifer is tapped by boreholes and is not vulnerable to pollution. It is the most productive and exploited aquifer in Lagos State. Indeed, more than 30\% of groundwater supply in Lagos and its environs tap from the CPS aquifer. This source complements the surface water from Adiyan, Iju, and Isashi. 
The major challenge of groundwater resources in the LCPS is over-abstraction due to increasing demand resulting from high population growth and increased industrial production. According to Longe (2011), the surface water sources are also no longer reliable due to pollution and attendant high cost of treatment. Thus, groundwater has continued to serve as the major source of water supply in the state due to its relatively better quality and availability through the various mini and micro waterworks. The mini and micro waterworks have a total design capacity of about $53.2 \mathrm{Mgd}$ and $16.3 \mathrm{Mgd}$, respectively. Corresponding total supplies are $2,797.38 \mathrm{Mgd}$ and $1,208.77 \mathrm{Mgd}$ (Lagos Water Corporation, 2012).

Sample collection and treatment: Data used for this study included those generated from a set of geological and topographical maps covering Sheet 68, the former having a scale of 1:250,000 while the latter has 1:50,000. The maps cover Lagos NE1 \& 2, Ibeju 280A, Ijebu-Ode 279 SE and SW. Groundwater samples were collected from forty-five (45) protected dug wells and stored in clean $150 \mathrm{ml}$ polyethylene bottles and preserved in ice chests for onward delivery to the Chemistry Department, University of Lagos, Akoka for analyses.

Depth to the water table and aquifer depth were measured using the sound meter and measuring tape with a plumb line, respectively. Some water quality parameters were also measured in-situ; $\mathrm{pH}$ was measured using a pocket $\mathrm{pH}-102$ meter (RoHS) after being calibrated with a standard buffer solution; EC was measured using EC DiST-3 meter (HANNA, HI 98303) while TDS was measured with the TDS/TEMP (HM Digital) meter. The cations $\left(\mathrm{Na}^{+} \mathrm{K}^{+}, \mathrm{Ca}^{2+} \mathrm{Mg}^{2+}\right.$ ) and anions $\left(\mathrm{Cl}^{-}, \mathrm{HCO}_{3}{ }^{-}, \mathrm{CO}_{3}{ }^{2-}\right.$ and $\mathrm{SO}_{4}{ }^{2-}$ were determined in the laboratory using standard methods as suggested by the American Public Health Association (APHA, 1998).

Co-ordinates of the sample locations were recorded with a global positioning system (GPS) (Garmin map, 76CSX model) and thereafter were exported into ArcMap 9.3 software to produce the map of the sampling locations (Fig.2).

Sample analysis: The data were analyzed using descriptive statistics. Paired sample T-test and multivariate statistical techniques were also employed as contained in the SPSS software 17.0 version to test for variation in the concentrations of the parameters induced by season. The results of the groundwater parameters were compared with the World Health Organization Standard (WHO) for potable water use in the study area.

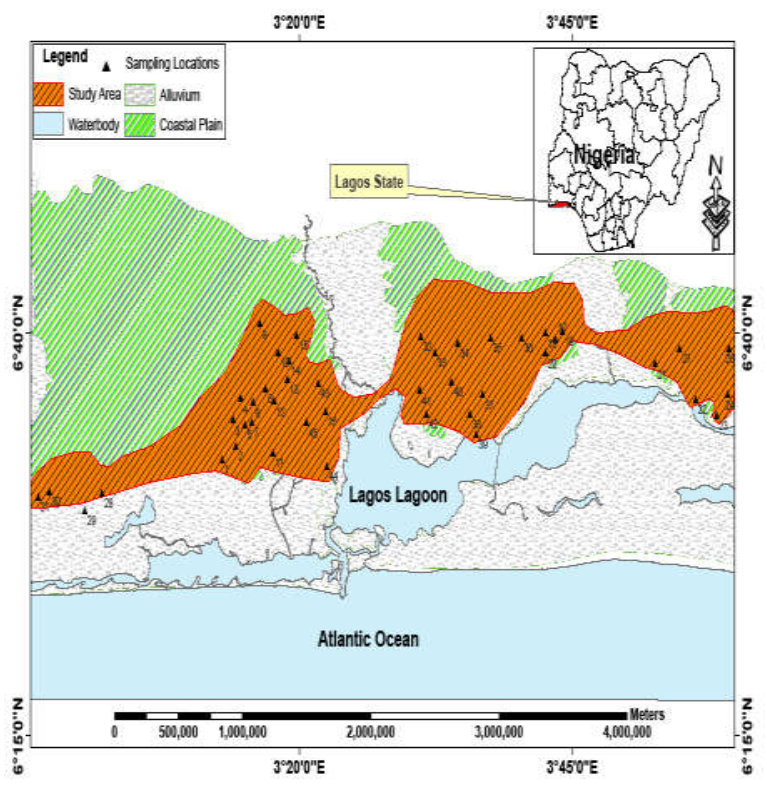

Fig. 2. Sampling Locations

\section{RESULTS AND DISCUSSION}

Well characteristics and physicochemical properties of groundwater: Depth to water table (DWT) ranged from 1.9 to $27.7 \mathrm{~m}$ and 0.8 to $29.2 \mathrm{~m}$ in the dry and wet seasons, respectively (Fig. 3). The corresponding mean was 14.84 and $15.16 \mathrm{~m}$. Aquifer depth was between 2.0 and $30.96 \mathrm{~m}$ with a mean of $17.48 \mathrm{~m}$. pH varied between 3.02 and 7.3 in the dry season and from pH3.6 to 7.4 in the wet. The corresponding mean was pH5.14 and 5.99. It was observed that in dry season all the sampling locations with the exception of Igando and Alausa had pH6.5 which is lower (more acidic) than the minimum prescribed by WHO (2006) for potable water. In the wet season, only 27 locations representing $60 \%$ of the sampling locations had a $\mathrm{pH}$ that is lower than the WHO standard. Figure 4 depicts the $\mathrm{pH}$ statistics compared with the WHO potable water standard.

EC ranged between 13 and $9,779 \mu \mathrm{Scm}$ with an average of $343.8 \mu \mathrm{Scm}^{-1}$ in the dry season while it was between 15 and $6,600 \mu \mathrm{Scm}$ with a mean of $276.36 \mu \mathrm{Scm}$ in the wet season. TDS varied from 10 to $4,890 \mathrm{mg} / \mathrm{L}$ in the dry season and between 11 and $3,300 \mathrm{mg} / \mathrm{L}$ in the wet season. The corresponding mean was 192.07 and $157.69 \mathrm{mg} / \mathrm{L}$ respectively. It was observed that in all the sampling locations, EC and TDS values were within the WHO limits of $1,000 \mu \mathrm{Scm}$ to $500 \mathrm{mg} / \mathrm{L}$ respectively except at Igando in both seasons. High values of these parameters can result from the infiltration of leachates from dump sites in the area. 


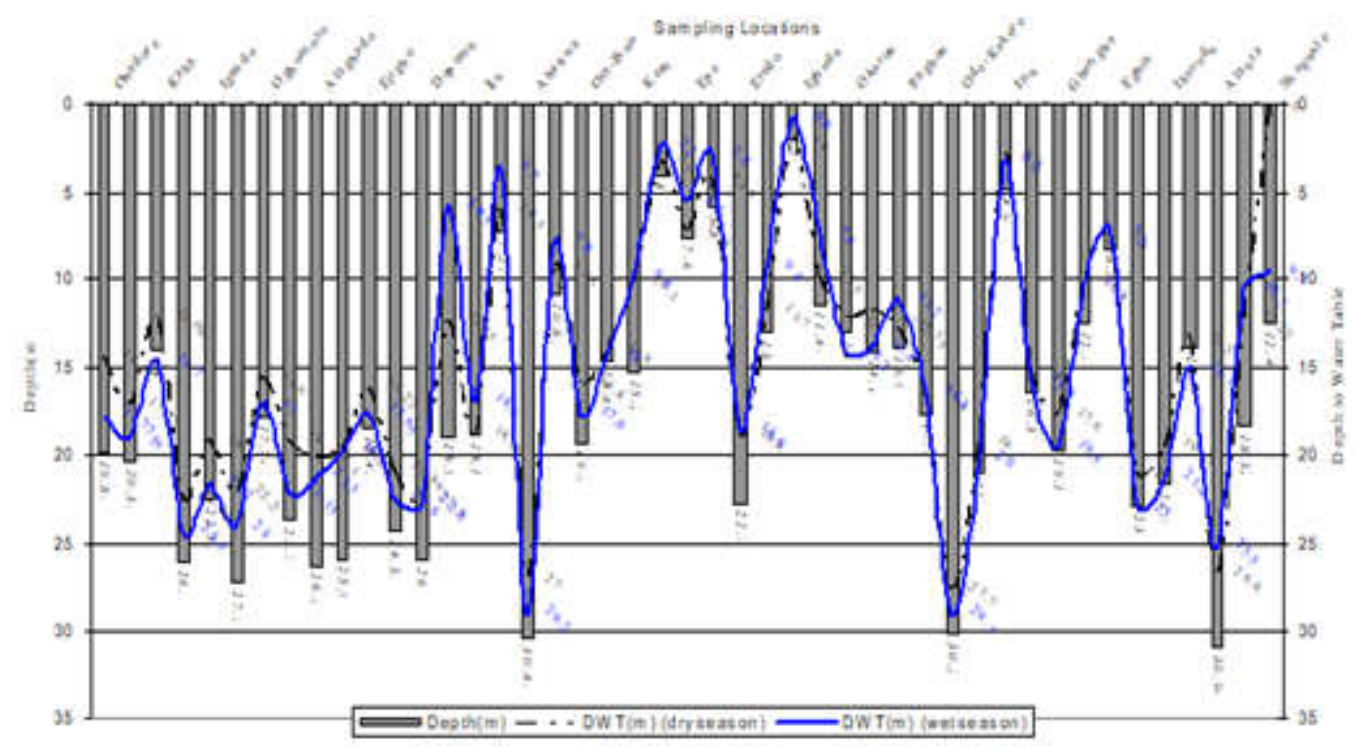

Fig. 3. Depth of Aquifer and Water Table Depth (DWT) in Dry and Wet Seasons

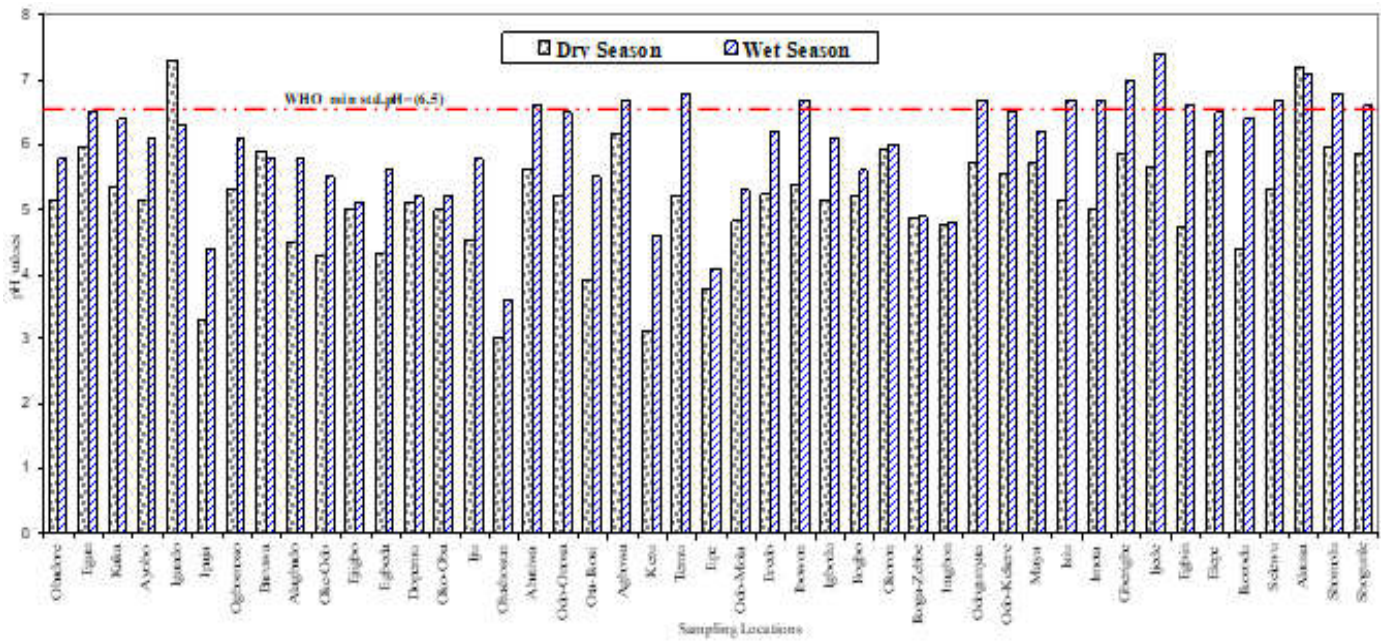

Fig. 4. Groundwater $\mathrm{pH}$ and WHO Potable Water $\mathrm{pH}$ Standard in Dry and Wet Seasons

$\mathrm{Na}$ and $\mathrm{Ca}$ varied between 1.87 and 1,350, 0.77 and $90 \mathrm{mg} / \mathrm{L}$, respectively. Both $\mathrm{Mg}$ and $\mathrm{K}$ were from 0.00 to 222 and 0.00 to $51.69 \mathrm{mg} / \mathrm{L}$, respectively. The corresponding means are 39.68, 25.56, 12.61 and $3.62 \mathrm{mg} / \mathrm{L}$ in the dry season. In all samples, the WHO limit of $30 \mathrm{mg} / \mathrm{L}$ was exceeded. In the wet season, $\mathrm{Na}$ fluctuated between 1.96 and $1,142 \mathrm{mg} / \mathrm{L} ; \mathrm{K}$ was from 0.08 to $1,102 \mathrm{mg} / \mathrm{L} ; \mathrm{Ca}$ varied between 11.00 and $43.1 \mathrm{mg} / \mathrm{L}$ while $\mathrm{Mg}$ was from 0.04 to $6.8 \mathrm{mg} / \mathrm{L}$. $\mathrm{Na}, \mathrm{K}$, $\mathrm{Ca}$ and $\mathrm{Mg}$ had a respective mean of $47.45,28.63$, 10.25 and $1.0 \mathrm{mg} / \mathrm{L}$. The high concentration of $\mathrm{Ca}^{2+}$ and $\mathrm{Mg}^{2+}$ can be attributed to the geology of the area (Todd \& Mays, 2005).

Chloride, bicarbonate, and sulfate ranged between 4 and $2,800,10$ and 286.6 and 1.2 to $82 \mathrm{mg} / \mathrm{L}$ with the corresponding mean of $92.24,85.34$ and $5.8 \mathrm{mg} / \mathrm{L}$ respectively in the dry season. In the wet season, chloride, bicarbonate, sulfate, and carbonates varied between 2.00 and 2,250, 8.00 and 228, 1.00 and 46.00 and under detection limit to $0.1 \mathrm{mg} / \mathrm{L}$, respectively. Correspondingly, these parameters were 77.2, 60.36, 4.71 and $0.03 \mathrm{mg} / \mathrm{L}$ on the average.

The high concentration of these parameters can be linked to infiltration of leachates from dump sites, sewage, and wastewater. In addition, $\mathrm{K}^{2+}$ exceeded WHO limit of $10 \mathrm{mg} / \mathrm{L}$ at Oko-Oba, Ilogbo, Shomolu and Shogunle in a dry season whereas in the wet season, it exceeded the WHO limits at Igando, OkoOba, Odo-Onosa, Ilogbo, Shomolu, and Shogunle. The observed high concentration of $\mathrm{K}^{2+}$ in these locations can also be linked with the geology of the area (Todd and Mays, 2005). Calcium is present in all natural waters although its level depends on the rock types through which the water flows. $\mathrm{Ca}^{2+}$ is usually 
present in the form of carbonates, bicarbonates, sulfate, chloride, and nitrate. $\mathrm{Ca}^{2+}$ plays a vital role in bone structure, muscle contraction, nerve impulse transmission, and blood clotting. About $99 \%$ of $\mathrm{Ca}^{2+}$ is found in bone and teeth while the remainder is in soft tissue. Low intake of $\mathrm{Ca}^{2+}$ has been reported to cause osteoporosis, rickets, and hypertension (Kurtz and Morris, 1993). Magnesium is one of the earth's most common elements and forms highly soluble salts. The high concentration of $\mathrm{Mg}^{2+}$ is undesirable in potable water because it causes scale formation, cathartic and diuretic effects. Though magnesium is an essential co-factor for more than 350 enzyme systems, it is also responsible for energy metabolism, nucleic acid synthesis, and cellular balance, cardiovascular and hormonal functions (Tuthill and Calabrese, 1991). Low magnesium intake is responsible for osteoporosis, increased calcium balance, insulin resistance, metabolic syndrome, increased oxidant stress and increased risk of cardiovascular disease (Tuthill and Calabrese, 1991).

Table 1. Paired sample statistics and correlation of groundwater parameters

\begin{tabular}{|c|c|c|c|c|c|c|}
\hline \multicolumn{2}{|c|}{ Parameters } & \multirow{2}{*}{$\begin{array}{l}\text { Mean } \\
5.148\end{array}$} & \multirow{2}{*}{$\begin{array}{l}\text { S.D } \\
0.882\end{array}$} & \multirow{2}{*}{$\begin{array}{l}\begin{array}{l}\text { Std. Error } \\
\text { Mean }\end{array} \\
0.131\end{array}$} & \multirow{2}{*}{$\begin{array}{l}\text { Correlation } \\
0.736\end{array}$} & \multirow{2}{*}{$\begin{array}{l}\mathrm{p} \text { - value } \\
0.000\end{array}$} \\
\hline Pair 1 & $\mathrm{pH}$ & & & & & \\
\hline & $\mathrm{pH}^{*}$ & 5.989 & 0.841 & 0.125 & & \\
\hline \multirow[t]{2}{*}{ Pair 2} & $\mathrm{EC}$ & 343.80 & 1444.980 & 215.405 & 0.999 & 0.000 \\
\hline & $\mathrm{EC}^{*}$ & 276.36 & 973.214 & 145.078 & & \\
\hline \multirow[t]{2}{*}{ Pair 3} & TDS & 192.07 & 721.246 & 107.517 & 0.998 & 0.000 \\
\hline & TDS* & 157.69 & 485.805 & 72.420 & & \\
\hline \multirow[t]{2}{*}{ Pair 4} & $\mathrm{Ca}^{2+}$ & 25.56 & 20.223 & 3.015 & 0.777 & 0.000 \\
\hline & $\mathrm{Ca}^{2+*}$ & 10.245 & 10.172 & 1.5163 & & \\
\hline \multirow[t]{2}{*}{ Pair 5} & $\mathrm{Mg}^{2+}$ & 12.61 & 32.775 & 4.886 & 0.161 & 0.291 \\
\hline & $\mathrm{Mg}^{2+*}$ & 1.000 & 1.369 & 0.204 & & \\
\hline \multirow[t]{2}{*}{ Pair 6} & $\mathrm{Na}^{+}$ & 39.676 & 200.106 & 29.830 & 0.991 & 0.000 \\
\hline & $\mathrm{Na}^{+*}$ & 47.450 & 169.037 & 25.199 & & \\
\hline \multirow[t]{2}{*}{ Pair 7} & $\mathrm{~K}^{+}$ & 3.624 & 7.962 & 1.1869 & 0.085 & 0.578 \\
\hline & $\mathrm{K}^{+*}$ & 28.629 & 163.847 & 24.425 & & \\
\hline \multirow[t]{2}{*}{ Pair 8} & $\mathrm{Cl}^{-}$ & 92.24 & 414.202 & 61.746 & 0999 & 0.000 \\
\hline & $\mathrm{Cl}^{-*}$ & 77.20 & 333.001 & 49.641 & & \\
\hline \multirow[t]{2}{*}{ Pair 9} & $\mathrm{HCO}_{3}^{-}$ & 84.451 & 57.627 & 8.591 & 0.883 & 0.000 \\
\hline & $\mathrm{HCO}_{3}^{-*}$ & 60.36 & 42.896 & 6.395 & & \\
\hline \multirow[t]{2}{*}{ Pair 10} & $\mathrm{SO}_{4}{ }^{2-}$ & 5.80 & 11.785 & 1.757 & 0.989 & 0.000 \\
\hline & $\mathrm{SO}_{4}{ }^{2-}$ & 4.71 & 6.518 & 0.972 & & \\
\hline
\end{tabular}

Table 2. Seasonal paired samples T-test of groundwater parameters

\begin{tabular}{|c|c|c|c|c|c|c|c|c|c|}
\hline & \multirow{3}{*}{ Variables } & \multicolumn{5}{|c|}{ Paired Differences } & \multirow{3}{*}{$\mathrm{t}$} & \multirow{3}{*}{$\mathrm{df}$} & \multirow{3}{*}{$\mathrm{p}$-value } \\
\hline & & \multirow[t]{2}{*}{ Mean } & \multirow{2}{*}{$\begin{array}{c}\text { Std. } \\
\text { Deviation }\end{array}$} & \multirow{2}{*}{$\begin{array}{l}\text { Std. Error } \\
\text { Mean }\end{array}$} & \multicolumn{2}{|c|}{$\begin{array}{c}95 \% \text { Confidence Interval } \\
\text { of the Difference }\end{array}$} & & & \\
\hline & & & & & Lower & Upper & & & \\
\hline Pair 1 & $\mathrm{pH}-\mathrm{pH}^{*}$ & -0.841 & 0.627 & 0.093 & -1.02951 & -0.652 & -8.998 & 44 & 0.000 \\
\hline Pair 2 & $\mathrm{EC}-\mathrm{EC}^{*}$ & 67.444 & 475.211 & 70.840 & -75.325 & 210.214 & 0.952 & 44 & 0.346 \\
\hline Pair 3 & TDS - TDS* & 34.378 & 238.035 & 35.484 & -37.136 & 105.891 & 0.969 & 44 & 0.338 \\
\hline Pair 4 & $\mathrm{Ca}^{2+}-\mathrm{Ca}^{2+*}$ & 15.3167 & 13.890 & 2.071 & 11.14364 & 19.489 & 7.397 & 44 & 0.000 \\
\hline Pair 5 & $\mathrm{Mg}^{2+}-\mathrm{Mg}^{2+*}$ & 11.613 & 32.583 & 4.857 & 1.8237 & 21.402 & 2.391 & 44 & 0.021 \\
\hline Pair 6 & $\mathrm{Na}^{+}-\mathrm{Na}^{+} *$ & -7.774 & 39.486 & 5.886 & -19.63666 & 4.089 & -1.321 & 44 & 0.193 \\
\hline Pair 7 & $\mathrm{~K}^{+}-\mathrm{K}^{+*}$ & -25.005 & 163.361 & 24.352 & -74.08424 & 24.074 & -1.027 & 44 & 0.310 \\
\hline Pair 8 & $\mathrm{Cl}^{-}-\mathrm{Cl}^{-*}$ & 15.040 & 83.241 & 12.409 & -9.968 & 40.048 & 1.212 & 44 & 0.232 \\
\hline Pair 9 & $\mathrm{HCO}_{3}^{-}-\mathrm{HCO}_{3}^{-*}$ & 24.096 & 28.213 & 4.206 & 15.6195 & 32.572 & 5.729 & 44 & 0.000 \\
\hline Pair 10 & $\mathrm{SO}_{4}^{2-}-\mathrm{SO}_{4}{ }^{2-*}$ & 1.093 & 5.426 & 0.809 & -0.537 & 2.723 & 1.352 & 44 & 0.183 \\
\hline
\end{tabular}

The presence of calcium and magnesium ions in water is responsible for total hardness $(\mathrm{TH})$ in water. $\mathrm{TH}$ is an important criterion for determining the suitability of water for various uses e.g. domestic, drinking, and industrial (Karanth, 1987). Sodium in the drinking water supply is a major health concern for most people with heart disease, hypertension, kidney disease, and circulatory illness. According to Baron (1997) increased intake of $\mathrm{Na}^{+}$is responsible for hypertension while the acute effect of high levels of $\mathrm{Na}^{+}$in drinking water may result to nausea, vomiting, convulsion, muscular twitching and rigidity and cerebral and pulmonary oedema (Baron, 1997). High intake of $\mathrm{Na}^{+}$ can also result in heart failure, gastrointestinal infections, loss of fluid leading to dehydration and permanent neurological damage in infants (Amjad et al., 2010). Low potassium can also result in excessive loss of extracellular fluid, excessive dieresis or prolonged malnutrition (Amjad et al., 2010). 
Table 3. Correlations Matrix of Parameters in the Dry Season

\begin{tabular}{|c|c|c|c|c|c|c|c|c|c|c|c|}
\hline \multicolumn{2}{|c|}{ Variable } & \multirow{2}{*}{$\begin{array}{l}\mathbf{p H} \\
1\end{array}$} & \multirow[t]{2}{*}{ EC } & \multirow[t]{2}{*}{ TDS } & \multirow[t]{2}{*}{$\mathrm{Ca}^{2+}$} & \multirow[t]{2}{*}{$\mathbf{M g}^{2+}$} & \multirow[t]{2}{*}{$\mathrm{Na}^{+}$} & \multirow[t]{2}{*}{$\mathbf{K}^{+}$} & \multirow[t]{2}{*}{$\mathrm{Cl}^{-}$} & \multirow[t]{2}{*}{$\mathrm{HCO}_{3^{-}}$} & \multirow[t]{2}{*}{$\mathrm{SO}_{4}{ }^{2-}$} \\
\hline pH & $\begin{array}{l}\text { Correlation } \\
\text { p-value }\end{array}$ & & & & & & & & & & \\
\hline \multirow[t]{2}{*}{ EC } & Correlation & $0.361^{*}$ & 1 & & & & & & & & \\
\hline & p-value & 0.015 & & & & & & & & & \\
\hline \multirow[t]{2}{*}{ TDS } & Correlation & $0.351^{*}$ & $1.00^{* * *}$ & 1 & & & & & & & \\
\hline & p-value & 0.018 & 0.00 & & & & & & & & \\
\hline \multirow[t]{2}{*}{$\mathrm{Ca}^{2+}$} & Correlation & 0.218 & 0.237 & 0.249 & 1 & & & & & & \\
\hline & p-value & 0.150 & 0.116 & 0.099 & & & & & & & \\
\hline \multirow[t]{2}{*}{$\mathbf{M g}^{2+}$} & Correlation & $0.421^{\text {** }}$ & $0.977^{* *}$ & $0.976^{* *}$ & $0.381^{* *}$ & 1 & & & & & \\
\hline & p-value & 0.004 & 0.00 & 0.00 & 0.010 & & & & & & \\
\hline \multirow[t]{2}{*}{$\mathrm{Na}^{+}$} & Correlation & $0.362^{*}$ & $0.998^{* *}$ & $0.997^{* * *}$ & 0.208 & $0.973^{* * *}$ & 1 & & & & \\
\hline & p-value & 0.015 & 0.00 & 0.00 & 0.170 & 0.00 & & & & & \\
\hline \multirow[t]{2}{*}{$\mathbf{K}^{+}$} & Correlation & 0.018 & 0.089 & 0.099 & -0.067 & 0.032 & 0.084 & 1 & & & \\
\hline & p-value & 0.905 & 0.561 & 0.517 & 0.662 & 0.836 & 0.583 & & & & \\
\hline \multirow[t]{2}{*}{ Cl. } & Correlation & $0.352^{*}$ & $0.999^{* * *}$ & $0.998^{* *}$ & 0.213 & $0.971^{* *}$ & $1.000^{* *}$ & 0.097 & 1 & & \\
\hline & p-value & 0.018 & 0.00 & 0.00 & 0.160 & 0.00 & 0.00 & 0.527 & & & \\
\hline \multirow[t]{2}{*}{$\mathrm{HCO}_{3}^{-}$} & Correlation & 0.036 & 0.022 & 0.019 & 0.078 & 0.059 & 0.022 & -0.064 & 0.018 & 1 & \\
\hline & p-value & 0.813 & 0.884 & 0.900 & 0.610 & 0.701 & 0.886 & 0.675 & 0.909 & & \\
\hline \multirow[t]{2}{*}{$\mathrm{SO}_{4}^{2-}$} & Correlation & $0.327^{*}$ & $0.991^{* *}$ & $0.992^{* *}$ & 0.242 & $0.965^{* *}$ & $0.989^{* *}$ & 0.069 & $0.990^{* *}$ & 0.012 & 1 \\
\hline & p-value & 0.028 & 0.00 & 0.00 & 0.109 & 0.00 & 0.00 & 0.652 & 0.00 & 0.935 & \\
\hline
\end{tabular}

Table 4. Correlations Matrix of Parameters in the Wet Season

\begin{tabular}{|c|c|c|c|c|c|c|c|c|c|c|c|c|}
\hline Variable & & $\mathrm{pH}$ & EC & TDS & $\mathrm{Ca}^{2+}$ & $\mathrm{Mg}^{2+}$ & $\mathrm{Na}^{+}$ & $\mathrm{K}^{+}$ & $\mathrm{Cl}^{-}$ & $\mathrm{HCO}_{3}^{-}$ & $\mathrm{SO}_{4}{ }^{2-}$ & $\mathrm{CO}_{3}{ }^{2-}$ \\
\hline \multirow[t]{2}{*}{$\mathrm{pH}$} & Correlation & 1 & & & & & & & & & & \\
\hline & $\mathrm{p}$-value & & & & & & & & & & & \\
\hline \multirow[t]{2}{*}{$\mathrm{EC}$} & Correlation & 0.014 & 1 & & & & & & & & & \\
\hline & $\mathrm{p}$-value & 0.928 & & & & & & & & & & \\
\hline \multirow[t]{2}{*}{ TDS } & Correlation & -0.012 & $0.999^{* *}$ & 1 & & & & & & & & \\
\hline & p-value & 0.936 & 0.00 & & & & & & & & & \\
\hline \multirow[t]{2}{*}{$\mathrm{Ca}^{2+}$} & Correlation & -0.084 & -0.010 & 0.012 & 1 & & & & & & & \\
\hline & p-value & 0.582 & 0.949 & 0.936 & & & & & & & & \\
\hline \multirow[t]{2}{*}{$\mathrm{Mg}^{2+}$} & Correlation & -0.222 & 0.176 & 0.186 & $0.297^{*}$ & 1 & & & & & & \\
\hline & $\mathrm{p}$-value & 0.142 & 0.248 & 0.220 & 0.048 & & & & & & & \\
\hline \multirow[t]{2}{*}{$\mathrm{Na}^{+}$} & Correlation & 0.009 & $0.994^{* *}$ & $0.994^{* * *}$ & -0.029 & 0.124 & 1 & & & & & \\
\hline & $\mathrm{p}$-value & 0.953 & 0.00 & 0.00 & 0.850 & 0.416 & & & & & & \\
\hline \multirow[t]{2}{*}{$\mathrm{K}^{+}$} & Correlation & 0.051 & $0.994^{* *}$ & $0.990^{* *}$ & -0.070 & 0.115 & $0.989^{* * *}$ & 1 & & & & \\
\hline & p-value & 0.738 & 0.00 & 0.00 & 0.649 & 0.452 & 0.00 & & & & & \\
\hline \multirow[t]{2}{*}{$\mathrm{Cl}^{-}$} & Correlation & 0.018 & $0.996^{* *}$ & $0.995^{* *}$ & -0.053 & 0.139 & $0.995^{* *}$ & $0.997^{* * *}$ & 1 & & & \\
\hline & p-value & 0.906 & 0.00 & 0.00 & 0.731 & 0.362 & 0.00 & 0.00 & & & & \\
\hline \multirow[t]{2}{*}{$\mathrm{HCO}_{3}^{-}$} & Correlation & $0.476^{* *}$ & $0.545^{* *}$ & $0.529^{* *}$ & -0.154 & -0.211 & $0.542^{* * *}$ & 0.586 & $0.564^{* *}$ & 1 & & \\
\hline & $\mathrm{p}$-value & 0.001 & 0.00 & 0.00 & 0.313 & 0.165 & 0.00 & 0.00 & 0.00 & & & \\
\hline \multirow[t]{2}{*}{$\mathrm{SO}_{4}^{2-}$} & Correlation & -0.037 & $0.974^{* *}$ & 0.976 ** & 0.022 & 0.176 & $0.979^{* *}$ & $0.967^{* *}$ & $0.974^{* *}$ & $0.525^{\text {** }}$ & 1 & \\
\hline & $\mathrm{p}$-value & 0.809 & 0.00 & 0.000 & 0.885 & 0.248 & 0.00 & 0.00 & 0.00 & 0.00 & & \\
\hline \multirow{2}{*}{$\mathrm{CO}_{3}{ }^{2-}$} & Correlation & -0.035 & $0.436^{* *}$ & $0.435^{* *}$ & 0.062 & 0.259 & $0.418^{* *}$ & $0.449^{* * *}$ & $0.440^{* *}$ & 0.293 & $0.448^{* *}$ & 1 \\
\hline & $\mathrm{p}$-value & 0.822 & 0.003 & 0.003 & 0.685 & 0.086 & 0.004 & 0.002 & 0.002 & 0.050 & 0.002 & \\
\hline
\end{tabular}

Chloride in drinking water is generally not harmful to humans except at high concentrations. Chloride may impart a salty taste to drinking water and can also exert a significant effect on the rate of corrosion of steel and aluminum or metals used in water handling systems. It can also result in gastrointestinal problems, irritation, diarrhea and dehydration (WHO, 1999).

Seasonal variations of groundwater parameters: The paired sample statistics and correlation of the 
examined parameters is presented in Table 1. The result shows that there are significant correlations at $\mathrm{p}<0.05$ among most of the examined parameters with the exception of $\mathrm{Mg}^{2+}$ and $\mathrm{K}^{+}$in both seasons. Similarly, the seasonal paired sample T-test shows significant variations among $\mathrm{pH}, \mathrm{Ca}^{2+}, \mathrm{HCO}_{3}{ }^{-}$and $\mathrm{Mg}^{2+}$ in the study area (Table 2).

Seasonal relationship of groundwater parameters: The seasonal relationships of groundwater parameters for both dry and wet seasons are presented in Tables 3 and 4 , respectively. The results show that there is a significant correlation at $p<0.05$ among EC and TDS in most of the parameters. The strong correlations among these parameters suggest anthropogenic impacts and marine influence on the groundwater system (Aiman and Mohamed, 2010; Rao et al., 2012).

Table 5. Rotated factor analysis in dry season

\begin{tabular}{lll}
\hline \multirow{2}{*}{ Parameters } & \multicolumn{2}{l}{ Factor Components } \\
\cline { 2 - 3 } & $\mathbf{F}_{\mathbf{1}}$ & $\mathbf{F}_{\mathbf{2}}$ \\
\hline $\mathrm{pH}$ & 0.40 & 0.32 \\
$\mathrm{EC}$ & 0.99 & 0.02 \\
$\mathrm{TDS}$ & 0.99 & 0.02 \\
$\mathrm{Ca}^{2+}$ & 0.26 & 0.62 \\
$\mathrm{Mg}^{2+}$ & 0.98 & 0.17 \\
$\mathrm{Na}^{+}$ & 0.99 & 0.01 \\
$\mathrm{~K}^{+}$ & 0.14 & -0.60 \\
$\mathrm{Cl}^{-}$ & 0.99 & 0.00 \\
$\mathrm{HCO}_{3}^{-}$ & -0.01 & 0.57 \\
$\mathrm{SO}_{4}{ }^{-}$ & 0.99 & 0.02 \\
$\%$ of variance & 61.84 & 11.64 \\
$\mathrm{Cumulative} \%$ & 61.84 & 73.48 \\
\hline
\end{tabular}

Table 6. Wet Season Rotated Factor Analysis.

\begin{tabular}{llll}
\hline \multirow{2}{*}{ Parameters } & \multicolumn{3}{c}{ Factor components } \\
\cline { 2 - 4 } & $\mathrm{F} 1$ & $\mathrm{~F} 2$ & $\mathrm{~F} 3$ \\
\hline $\mathrm{pH}$ & -0.06 & 0.92 & -0.05 \\
$\mathrm{TC}$ & 0.99 & 0.06 & 0.07 \\
$\mathrm{Ca}^{2+}$ & 0.99 & 0.04 & 0.08 \\
$\mathrm{Mg}^{2+}$ & -0.09 & 0.04 & 0.82 \\
$\mathrm{Na}^{+}$ & 0.15 & -0.32 & 0.72 \\
$\mathrm{~K}^{+}$ & 0.99 & 0.05 & 0.02 \\
$\mathrm{Cl}^{-}$ & 0.99 & 0.10 & 0.00 \\
$\mathrm{HCO}_{3}{ }^{-}$ & 0.99 & 0.07 & 0.02 \\
$\mathrm{SO}_{4}{ }^{2-}$ & 0.55 & 0.69 & -0.15 \\
$\mathrm{CO}_{3}{ }^{2-}$ & 0.98 & 0.02 & 0.09 \\
$0_{0}$ of variance & 0.47 & 0.10 & 0.39 \\
$\mathrm{Cumulative} \%^{2}$ & 59.36 & 15.58 & 9.27 \\
\hline
\end{tabular}

Multivariate statistics of the seasonal variations of groundwater parameters: The results of the factor analysis (FA) in dry season indicate that two factors explain $74.48 \%$ of the total variances (Table 5). Factor I accounts for $61.84 \%$ of the total variance with strong loading on $\mathrm{EC}, \mathrm{TDS}, \mathrm{Na}^{+}, \mathrm{Cl}^{-}, \mathrm{SO}_{4}{ }^{2-}$, and $\mathrm{Mg}^{2+}$. These parameters represent seawater constituents (Lu et al., 2012). Factor II accounts for $11.64 \%$ of the total variance and is characterized by medium loadings of $\mathrm{Ca}^{2+}, \mathrm{K}^{+}$and $\mathrm{HCO}_{3}{ }^{-}$. In the wet season, the rotated factor matrix accounted for $84.21 \%$ of the total variance (Table 6).

The wet season FA shows that factor I accounts for $59.36 \%$ of the total variance, with high loadings on $\mathrm{Cl}^{-}$ , EC, $\mathrm{Na}^{+}, \mathrm{K}^{+}, \mathrm{TDS}$, and $\mathrm{SO}_{4}{ }^{2-}$. These parameters $\left(\mathrm{Cl}^{-}\right.$, $\mathrm{Na}^{+}, \mathrm{K}^{+}$, and $\mathrm{SO}_{4}{ }^{2-}$ ) represent the dominant components of salinity and anthropogenic impacts on the groundwater system (Aiman and Mohamed, 2010; Lu et al., 2012). Factor II accounts for $15.58 \%$ of the total variance and is characterized by high to medium positive loading of $\mathrm{pH}$ and $\mathrm{HCO}_{3}{ }^{-}$. While factor III accounts for $9.27 \%$ of the total variance and is characterized by strong and medium positive loading of $\mathrm{Ca}^{2+}$ and $\mathrm{Mg}^{2+}$ respectively (Table 6). The application of FA to reduce the number of parameters needed to explain the groundwater data in the study area is medium because eight out of the parameters were needed to explain $73.48 \%$ of the variance in the data set across two factors comprising of ten parameters in the dry season. In the wet season, eight out of the parameters were needed to explain $84.21 \%$ of the variance in the data set across the three factors comprising eleven parameters. It is to be noted that the application of FA in this study successfully identified the most significant sources of pollution in the groundwater of the study area.

Conclusion: The findings of this study revealed that DWT is relatively high in the wet season compared to the dry season. The degree of the seasonal relationship between the examined parameters shows significant correlations at $\mathrm{p}<0.05$ with the exception of $\mathrm{Mg}^{2+}$ and $\mathrm{K}^{+}$in both seasons. Furthermore, the seasonal paired sample $\mathrm{T}$-test also shows significant variations among four parameters, $\mathrm{pH}, \mathrm{Ca}^{2+}, \mathrm{HCO}_{3}^{-}$and $\mathrm{Mg}^{2+}$ while Factor analysis also suggests that the two major factors responsible for pollution are salinity and anthropogenic activities undertaken in the study area. Consequently, it is recommended that protection of recharge areas of the aquifer from environmental pollution resulting from various human activities is essential.

\section{REFERENCES}

Adelana, SMA; Olasehinde, PI; Bale, RB; Vrbka, P Edet, AE ; Goni, IB (2008). An overview of the geology and Hydrogeology of Nigeria. In S.M.A Adelana \& A.M. MacDonald (Eds.), Appl groundwater studies in Africa. 171-197. Netherlands, Taylor \& Francis.

Ahmad, H El-Jablawi, SW (2007).Water quality assessment of Lebanese coastal rivers during dry season and pollution load into the Mediterranean Sea. J of Water and Hea, 5 (4): 615-623. 
Aiman, AL Mohamed, E (2010). Groundwater investigation in Awlad Salameh, Southern Sohag, Upper Egypt. Earth Sci Res J, 14 (1): 63-75.

American Public Health Association (APHA), (1998). Standard methods for the examination of water and wastewater, 20 ${ }^{\text {th }}$ edn., American Public Health Association, (APHA), American Water Works Association/Water Environment Federation, Washington, 2005-2605.

Amjad, AB; Mohammad, ID; Parveez, IP (2010). Chemical characteristics of drinking water of Peshawar. Pakistan J Nut, 9 (10): 1017-1027

Ansa-Asare,OD Gordon, C (2012). Water Quality Assessment of Densu, Birim and Ayensu Rivers in the Okyeman Area. West Afr J Appl Eco, 20 (3): 53-64

AQUASTAT. (2011). Online database. Rome, Food and Agriculture Organization of the United

Nations

(FAO).http://www.fao.org/nr/water/aquastat/data lquery/index. html

Asiwaju-Bello, YA; Oladeji, OS (2001). Numerical modelling of ground water flow patterns within Lagos metropolis, Nigeria. Nigerian J of Min and Geol, 37, 185-194.

Ayeni, AO; Balogun, II; Soneye, ASO (2011). Seasonal assessment of physical-chemical concentration of polluted urban River: A Case of Ala River in South - western Nigeria. Res J Environ Stud. 5 (1): 21-33

Balogun, II; Akoteyon, IS; Adeaga, O (2012). Evaluating land use effects on groundwater quality in Lagos-Nigeria using Water Quality Index. J Sci Res, 4 (2): 397- 409

Baron, J (1997). Repair of wastewater microorganisms after ultraviolet disinfection under semi-natural conditions. Water Environ Res 69 (5) : 992-998

Bonvallot, V(2003). L'arsenic quotidian Biofutur, 232, 70-3.

Celik, M Yildirim, T (2006). Hydrochemical evaluation of groundwater quality in the Cavuscayi Basin, Sungurlu-Corum, Turkey, J of Environ Geol 50, 323-330
Comprehensive Assessment of Water Management in Agriculture. (2007). Water for Food, Water for Life: A Comprehensive Assessment of Water Management in Agriculture. London/ Colombo, Earthscan/ International Water Management Institute (IWMI).

Dabrowski, JM; de Klerk, LP (2013). An assessment of the impact of different land use activities on water quality in the upper Olifants River catchment, Water SA, 39 (2), 231-244.

Esteller, MV; Rodríguez, R Cardona, A PadillaSánche, L (2012). Evaluation of hydrochemical changes due to intensive aquifer exploitation: case studies from Mexico. Environ Monit Assess 184 (9), 5725-5741.

Federal Ministry of Water Resources (2007). Organization and Activities. Federal Republic of Nigeria.

http://aochycos.ird.ne/HTMLF/PARTNAT/FED

WATER/INDEX/HTM accessed 28th February.

Güler, C Thyne, GD (2004). Hydrologic and geologic factors controlling surface and groundwater chemistry in Indian wells - Owens Valley area, southeastern California, USA. J. Hydrol. 285, 177-198.

Ince, M Bashir, D Oni, OOO; Awe, EO; Ogbechie, V Korve, K (2010). Rapid assessment of drinking water quality in the Federal Republic of Nigeria country report of the pilot project Implementation in 2004-2005, World Health Organization and UNICEF publications.

Jamshidzadeh, Z Mirbagheri, SA (2011). Evaluation of groundwater quantity and quality in the Kashan Basin, Central Iran. Desalination 270, 23-30.

Karanth, KR (1987) Groundwater assessment, development and management. Tata McGrawHill publishing Comp. Ltd, New Delhi, 716.

Kurtz, TW Morris, RC (1993) Dietary Chloride as a determinant of Sodium dependent hypertension. Science, 222, 1139-1141.

Lagos Water Corporation. (2012). Digest of Statistics. Lagos Bureau of Statistics, Ministry of Economic Planning and Budget Publication, 203-205.

Longe, EO; Malomo, S Olorunniwo, MA (1987). Hydrogeology of Lagos metropolis. J. Afr. Earth Sci., 6 (3): 163-179. 
Longe, EO (2011). Groundwater resource potential in the Coastal Plain Sands Aquifers, Lagos, Nigeria. Research J of Environ and Earth Sci, 3 (1): 1-7.

Lu, KL; Liu, CW; Jang, CS (2012). Using multivariate statistical methods to assess the groundwater quality in an arsenic-contaminated area of Southwestern Taiwan. Environ Monit Assess 184 (10): 6071-6085.

Mishra, PC; Behera, PC; Patel, RK (2005). Contamination of water due to major industries and open refuse dumping in the steel city of Orissa: A case study, ASCE, J. Environ. Sci. Eng. 47 (2): 141-154.

Morris, BL; Lawrence, AR; Chilton, PJ; Adams, B Calow, R. Klinck, BA (2003).Groundwater and its susceptibility to degradation: a global assessment of the problem and options for management, Early Warning and Assessment Report Series, United Nations Environment Programme, Nairobi, Kenya, Report RS 03-3, 1126.

Odumosu, T Balogun, Y Ojo, K (Eds.). (1999). Lagos State in Maps. Ibadan: Rex Charles Press.

Partey, F.K. Land, L.A. \& Frey, B. (2010): Final Report of the Geochemistry of Bitter Lakes National Wildlife Refuge, New Mexico Bureau of Geology and Mineral Resources, Roswell, New Mexico, 2010, 19.

Rao, NS; Rao, PS; Reddy, GV; Nagamani, M Vidyasagar, G Satyanarayana. NL (2012) . Chemical characteristics of groundwater and assessment of groundwater quality in Varaha River Basin, Visakhapatnam District, Andhra Pradesh, India. Environ Monit Assess 184 (8): 5189-5214

Shweta, T Bhavtosh, S Prashant, S Rajendra, D (2013). Water Quality Assessment in Terms of Water Quality Index. Ame J of Water Res, 1 (3): 34-38.

Stellar, D (2010). Can we have our water and drink it, too? Exploring the water quality-quantity nexus. State of the Planet blog. New York, Earth Institute, Columbia University.http://blogs.ei.columbia.edu/2010/10/ 28/can-we-haveour-water-and-drink-it-tooexploring-the-water-quality-quantity-nexus/
Thyne, G Guler, C Poeter, E (2004). Sequential analysis of hydrochemical data for watershed characterization. Ground Water 42,711-723,

Todd, DK; Mays, LW (2005). Groundwater Hydrology $3^{\text {rd }}$ edn., NY: John Wiley \& Sons, 625

Tu, J (2011). Spatial variations in the relationships between land use and water quality across an urbanization gradient in the watersheds of Northern Georgia, USA. Environ Mangt, 51 (1): $1-17$

Tuthill, RW; Calabrese (1991). Drinking water Sodium and Blood pressure in Children: A Second look. Am. J. Pub Health, 71,722-729.

UNEP (United Nations Environment Programme). (2010): Clearing the Waters. A Focus on Water Quality Solutions. Nairobi, UNEP. http://www.unep.org/PDF/Clearing the Waters. pdf

UNESCO. (2012). Managing water under uncertainty and risk. The United Nations World Water

Assessment Programmee Report 4 (1): 1-909.

Vincent, KN; Ebenezer, KH, Smile, KA (2012). Analysis of Leachates from Solid Waste

Dumpsites: A Tool for Predicting the Quality of Composts Derived from Landfills. $J$ of Environ and Earth Sci, 2 (11): 8-20.

WHO (1999). Guidelines for drinking water quality, Int. Health criteria and other supporting Information. $2^{\text {nd }}$ edn., World Health Organization Geneva, 2,195-201.

World Health Organization. (2006). Guidelines for drinking water quality. First Addendum, $3^{\text {rd }}$ edn., 1, 491- 493.

WHO (World Health Organization). (2008). The Global Burden of Disease: 2004 Update.

Geneva, WHO. http: //www.who.int/healthinfo/global_burden_disease /GBD_report_2004update_full.pdf

WWAP (World Water Assessment Programme). (2009): United Nations World Water Development Report 3: Water in a Changing World. Paris/London, UNESCO Publishing/ Earthscan.

Yidana, SM; Yidana, A (2010). Assessing water quality using water quality index and multivariate analysis. Environ Earth Sci, 59, 1461-1473 